\title{
Evaluating Compliance to Food Safety and Hygiene Standards in Selected Delhi Based Catering Establishments as per Schedule IV of Food Safety and Standard Regulation, 2011 under FSS Act, 2006

\author{
Veena Kumari ${ }^{1}$, Deeksha Kapur ${ }^{2}$
}

${ }^{1}$ Research Scholar, School of Continuing Education, Indira Gandhi National Open University, New Delhi, India 2Professor, School of Continuing Education, Indira Gandhi National Open University, New Delhi, India

\section{ABSTRACT}

Background: Schedule 4 introduces the concept of Food Safety Management System (FSMS ) based on implementation of Good Manufacturing Practices (GMP) and Good Hygiene Practices (GHP) by food businesses. This study was conducted to evaluate compliance to food safety and hygiene standards in the selected Delhi based catering establishments as per schedule 4 of Food Safety and standards Regulations 2011.

Methods : Twenty four Catering Establishments were selected for the study using snowball sampling technique from all the nine districts of Delhi between September 2016 to February 2017.The observational checklist was developed and used using the pre-requisites of FSSAI system, Schedule 4 to gather data on quality and quantity of physical facilities. The observational checklist was set up with 3 points for qualifying the norm, 2 point for partially qualifying and 1 point for not qualifying. The minimum and maximum possible score of the sanitation survey was between 67-201.The establishments were given grades on the basis of obtained scores : Exemplar $(A+G r a d e)=89.1-100 \%$, Compliance (A Grade) $=81-89 \%$, Needs Improvement (B Grade) $=72-80.9 \%$ and No Grade $=<71.9 \%$. Descriptive analysis was done using MS Excel and SPSS Software Version 21.

Results: The mean sanitation survey score of 24 catering establishment was $135.41 \pm 17.19$ with a median and mode of 133 and 132respectively.The establishments lowest and maximum score ranged between 101-177. Only $8 \%$ (2) of the catering establishments had provided uniform to $100 \%$ staff members, $84.0 \%$ (16) failed to provide adequate hand washing facilities. Potable water was provided by $75 \%$ (18) of the catering establishments and 33.3\% (8) of the catering establishments failed to provide information about the source of ice as they were not making ice at their premises. Record maintenance with respect to temperatures specifically was very poor and $65.3 \%$ (15) failed to comply the guidelines. Ideal thawing procedures were not followed by the $54 \%$ (13) of the catering establishments .But ,one good thing observed was that $100 \%$ (24) of the catering establishments were cooking food at ideal temperatures.

Conclusions: Catering establishments were expected to adhere to the set standards but the sanitation survey scores had surfaced their substandard sanitary conditions which needs improvement

Keywords : Food Safety Management System, Good Manufacturing Practice, Good Hygiene Practice.

\section{INTRODUCTION}

Food safety is a public health concern and is the key to sound health. People expect safe food and clean environment in food service establishments. Lack of basic infrastructure, under staffing, lack of knowledge of hygiene, absence of potable water, use of unhygienic material, not keeping food at safe temperature, lack of proper storage facility and unsuitable environments for food operations (such as proximity to sewers and garbage dumps) can contribute to outbreaks of food borne illnesses. 
Inadequate facilities for garbage disposal posed further hazards ( Kibret M and Abera B, 2012.). In addition poor sanitary practices in food storage, handling, and preparation can create an environment in which bacteria and other infectious agents easily grow, multiply and transmit ( Fielding JE, et al , 2001, Gent RN et al.,1999). Hence for providing safe foods, the various features should be considered initiating from selection of site, designing of premises, kitchen layout, selecting equipment, food service area, storage, drainage, altogether plays an important role in preventing the outbreak of food borne illness and thus comes under food safety practices.

The Food Safety and Standards Authority ( FSSAI) of India has laid down science based standards for articles of food and to regulate their manufacture, storage, distribution, sale and import, to ensure availability of safe and wholesome food for human consumption. The FSS Act 2006, replaced all the other food laws existing in the system including Prevention of Food Adulteration ( PFA) ACT, 1954 and FPO etc. This is an integrated Food Law and has created unified framework for food regulations which has shifting primary responsibility of safety to food businesses and hence assuring food safety across the food chain and ensuring uniform application of standards and practices across the country. Thus, ONE NATION ONE FOOD LAW.As per the condition of license under FSS (Licensing \& Registration of Food Businesses) Regulations 2011, every food business operator (FBO) applying for licensing must have a documented FSMS plan and comply with schedule 4 of this regulation. Schedule 4 introduces the concept of FSMS based on implementation of Good Manufacturing Practices (GMP) and Good Hygiene Practices (GHP) by food businesses and is divided into five parts as shown in table 1 ( FSS Regulation, 2011).
Table 1 : Schedule 4 General hygienic and sanitary practices to be be followed by all kinds of food business operators

\begin{tabular}{|c|c|}
\hline Schedule 4 & General Requirements \\
\hline Part 1 & $\begin{array}{l}\text { General hygienic and sanitary } \\
\text { practices to be followed by food } \\
\text { business operators applying for } \\
\text { registration - Petty food operators } \\
\text { and Street food vendor }\end{array}$ \\
\hline Part 2 & $\begin{array}{l}\text { General hygienic and sanitary } \\
\text { practices to be followed by food } \\
\text { business operators applying for } \\
\text { license manufacturing/ processing/ } \\
\text { packaging/storage/distribution }\end{array}$ \\
\hline Part 3 & $\begin{array}{l}\text { General hygienic and sanitary } \\
\text { practices to be followed by food } \\
\text { business operators applying for } \\
\text { license for milk and milk products }\end{array}$ \\
\hline Part 4 & $\begin{array}{l}\text { General hygienic and sanitary } \\
\text { practices to be followed by food } \\
\text { business operators applying for } \\
\text { license for slaughter house and meat } \\
\text { processing }\end{array}$ \\
\hline Part 5 & $\begin{array}{l}\text { General hygienic and sanitary } \\
\text { practices to be followed by food } \\
\text { business operators applying for } \\
\text { license catering }\end{array}$ \\
\hline
\end{tabular}

Source : Food Safety And Standards (Licensing And Registration Of Food Businesses), Regulations 2011.

\section{RATIONALE OF THE STUDY}

Food hygiene and sanitation in food service establishments, play an important role in food safety. With volume processing and preparation of food in catering establishments the effect of contamination is accentuated which could be due to :Human errors (as cross-contamination, time and temperature abuse, and poor personal hygiene) and Non human errors 
( environmental violations, such as poor maintenance and lack of facilities) (Choung, J. 2010 ). Numerous research studies had been conducted worldwide as well as in India in the area of food safety in fast moving food chains, restaurants, hospital /school/ college canteens with respect to HACCP and FSMS but studies specific to the Food Safety and Standards Rules and Regulations 2011 had not been conducted which is working on a 'one-nation, one-food-safetylaw'. ( FSSAI, 2011).

\section{Purpose of the Study}

The purpose of the study was to assess the readiness and preparedness of the Selected Catering Establishments in providing infrastructure facilities and promoting GMP and GHP according to the schedule 4 of Food Safety and Standard Regulation , 2011 under FSS Act ,2006.

\section{Assumptions of the Study}

For the purpose of this study, the following assumptions had been made:

1. Catering establishments owners had provided facilities as per the Food Safety and Standards ( Licensing and Registration of food businesses) Regulations ,2011.

2. Catering Establishments were aware of FSSAI Compliances and GMP, GHP and other faclilies were up to the mark.

\section{Significance of the Study}

The results will be of great importance to the Food Business Operators (FBO) and the policy makers. First, the Food Business Operators will get to know the bare minimum facilities to be maintained so that they can become a responsible place to eat rather a potential source to cause food borne illness and outbreak. Secondly the policy-makers will get a deeper insight towards existing infrastructure facilities and can monitor the premises by planning frequent audits.

\section{Scope of the Study}

Research will highlight commitment by the selected catering establishment in relation to determining food safety standards and procedures and and how much relaibale are they in serving safe and wholeome to consumers.

\section{Limitations}

1. The responses obtained from volunteered catering establishments may or may not represent the larger population. Since, the study was limited to urban vegetarian catering establishments and the sanitation ratings and infrastructure can't be similar for urban non vegetarian catering establishments, street food vendors, rural catering establishments, school/college/hospital canteen and road side dhabas etc.

2. Many of the catering establishments were not willing to participate in the study .References were used to get an access to the catering establishment which cannot be considered as a proper representation of the population. Thus, samples selected from the city cannot be considered as a proper representation of the population of the country.

\section{Conceptual Framework Based On The Schedule IV Of FSS Act , 2006}

This present study had identified both dependent and independent variables (figure1 below) which would have positive or negative effect on food safety in catering establishments. 


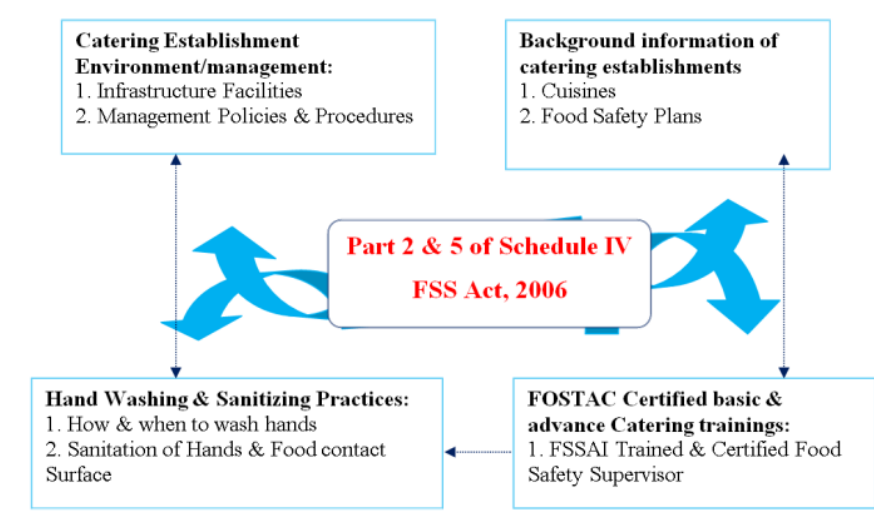

Figure 1 : Conceptual Framework based on Schedule 4 , FSS Act, 2006

\section{REVIEW OF LITERATURE}

The need for food safety is driven by consumers, the food industry and public health agencies. Food processors have an obligation to ensure they produce the safest food possible. Food regulations are the foundation for a successful food safety system (Motarjemi, Y. et al. (1999)) ). These regulations are further enhanced by GMP or GHP as per schedule 4 guidelines of Food Safety and Standard Regulation , 2011 under FSS Act, 2006. Legal requirements and industry guidelines have become more demanding and sophisticated, obligating food businesses to establish effective food safety management systems (FSMS). In the absence of food safety measures and compliances in food service establishments, there can be the outbreak of food borne illness which costs life and money. Millions of people die or become sick after eating contaminated foods.However, the World Health Organization's Foodborne Disease Burden Epidemiology Reference Group estimated that there were 582 million cases and 351,000 deaths associated with 22 different foodborne enteric diseases in 2010 (WHO FERG group, 2010). These diseases and deaths are usually linked to a breakdown in food safety programs because of improper human behaviour or an inappropriate food safety culture (Griffith, 2010 and Jespersen and Huffman, 2014). Taylor said: "We have too much foodborne illness. It's largely preventable. There's a lot that has been done to reduce risk, and there's a lot more that can be done" (CNN Wire,2018).Therefore, integrated approach should be considered right from selection of site, designing of premises, kitchen layout, storage, transportation, food service area and waste management. The site of premises should be such that surrounding should be cleaned, neat and in pollution-free area. Suitable arrangements of disposing of garbage which can minimize the risk of pests and cross contamination. The building should be constructed in a way that it allows a good flow pattern for handling foods from receiving to serving of food. The facilities must include food receiving area, storage area, preparation area, three sink dish cleaning and sanitizing area, service area, washroom and locker area. Floors, walls and ceilings should be durable, smooth, non-absorbent, easy to clean and maintain. Doors and windows should be made rodent proof, hard, smooth, durable, non-absorbent surface that can be cleaned easily. They should be fitted with fly- proof screens and it should be made pest proof. Exhaust fan should be equipped in food preparation area to ensure good circulation of air and to facilitate the removal of contaminated air and excessive heat. Washroom, restroom should be properly separated from food handling areas. No pitted utensils to be used for cooking and serving food and should be made of such materials that it does not affect the colour, taste and odour of food under normal condition. Food should be protected from time and temperature abuse. Food is to be thawed either in refrigerator or microwave before cooking and enough time should be provided to thaw thoroughly. Food should never be thawed at room temperature. Cooking, cooling and reheating to be done as per prescribed standards (FSMS).

\section{Personal Hygiene of Food Handlers}

The food processing staff should include healthy individuals who do not have any diseases, and they should undergo regular medical check-ups. The 
hygiene practices that should be performed by food processing workers include precise adherence to personal hygiene regulations and wearing of special, protective attire (Codex Alimentarius,2009). The practice of improper hand washing may be an important factor in the spreading of foodborne diseases by cross-contamination ( Cogan , Slader , Bloom Weld and. Humphrey,2002 and Collins, 2001). It was also reported that food processing and food service workers were the asymptomatic carriers of the pathogens which caused food poisoning, due to their failure to wash their hands properly after using the restroom (Temelli, C.M.K. , Anar, 2007).

\section{METHODOLOGY}

An observational cross sectional study was conducted to assess the selected catering establishment conditions and their commitment to follow food safety standards in Delhi between September 2016 to February 2017.The observational checklist was developed using the pre-requisites of FSSAI ,2011, Schedule 4, Part $2 \& 5$. The checklist contained 10 categories with 67 items and was used to gather data on quality and quantity of physical facilities. It included items related to the type of establishment, infrastructure layout, design and other faciliites like floor, walls, doors, screening of openings, air quality and ventilation, lighting,waste disposal, equipment and utensil washing facilities, procurement of raw materials and its storage, pest and rodent control, personal hygiene and health Status of food handlers, time and temperature control, food packaging and its distribution, food testing facilities, internal and external trainings and audit records, product information and consumer awareness .The observational checklist was set up with 3 points for qualifying the norm, 2 point for partially qualifying the norm and 1 point for not qualifying the norm. The minimum and maximum possible score of the sanitation survey was between 67-201. The establishments were given grades on the basis of obtained scores : Exemplar (A+Grade) $=89.1-100 \%$, Compliance (A Grade) $=81-89 \%$, Needs Improvement (B Grade) $=72-80.9 \%$ and No Grade $=<71.9 \%$.

\section{Study Area}

The study was conducted in selected catering establishments located in Delhi, the Capital of India which is the second most populous city in India. It is a place of amalgamation of several cuisine styles for people who came from different parts of the country and settled in Delhi. Delhi is known for two things rich culture and mouth watering food and the Capital is called "Delhi-Belly"(Julie Raj,2012).Delhi has been virtually divided into nine districts as North, South, East, West and Central, North west, North East, South West and New Delhi District.

\section{Data Collection Procedure}

The Catering Establishment for the study were selected from all the nine districts of Delhi using snow ball non probability sampling technique between September 2016 to February. Snow ball sampling technique was used to select catering establishment from all the nine districts of Delhi. Snowball sampling method is based on referrals from initial subjects to generate additional subjects via chain referral (Dudovskiy John.2018). The Sanitation survey was made to assess the extent to which catering establishments confirm to food safety standard operating procedures using observational checklist. The sanitation and hygienic status of catering establishment and the practices of food handlers at work recorded in the presence of the manager on duty without distracting the workers and the customer around. The back end area included receiving area, cold rooms, central stores , preparation area were also visited were visited and evaluated in terms of cleanliness and availability of facilities as prescibed in schedule 4 under FSS Act, 2006 and were scored accordingly. The collected data 
was analysed using MS Excel and SPSS Software Version 21 and the results were expressed in mean $+\mathrm{SD}$, median, mode, range or proportions wherever relevant.

\section{Inclusion Criteria of Catering Establishment:}

Establishment Category: Catering Establishment involved in processing ,handling ,storing, serving and packing of food.

$\checkmark$ Business Ownership: Private Limited / Proprietorship/Partnership

$\checkmark$ Type : Family Restaurant

$\checkmark$ License Category State/Central .The presence of licence was checked by observing the legal certificate.

$\checkmark$ Restaurant size: Medium with seating capacity of 40 -100 customer

$\checkmark$ Service: Self Service

$\checkmark$ Cuisines : Must serve North Indian and Traditional sweets

$\checkmark$ Food Specializations: Pure Vegetarian

$\checkmark$ Average Coupon Size: Rs 500 for two persons plus minus $10 \%$ ( Non festival season)

$\checkmark$ Sale : More than Rupees12 lac per annum

\section{Exclusion Criteria for Catering Establishments}

$\checkmark$ Catering establishment who didn't give permission was not selected for the study

$\checkmark$ Catering establishments not serving North Indian Food was not included in the study.

$\checkmark$ Catering establishment had bars and fine dining service was not included in the study.

$\checkmark$ Catering establishment not serving pure vegetarian food was not selected for the study.

$\checkmark$ Catering establishment not carrying a license at the time of study was not included in the study.

\section{Pilot Study}

The observational checklist was pilot tested on a simple random sample in non participating catering establishment before carrying out the formal phase of qualitative research. Pretesting instruments helped to ascertain that the instrument for collecting data was free from any flaws, errors, pitfalls and mistakes that would have come into notice while collecting the main data, if the pretesting of the instrument had not been done. After pilot study, the instrument was revised and refined to enhance the reliability and validity of the final tools.

\section{Ethical Considerations}

Ethical approval and clearance was obtained from the university and respective authorities from the catering establishments. Before collecting data the aim and objectives of the study were fully explained to the owners of catering establishment , managers/supervisors and food handlers. The consent form was given to each participating establishment who agreed to take part in the study. The signed consent was taken from the managers and owners. Also, the rights were givn to them to withdraw their names anytime from the study or they could refuse to answer any question. Participation in the study was purely on voluntary basis. Participants identification was also kept confidential.

\section{RESULTS}

The catering establishment conditions and their commitment to follow food safety standards and procedures were evaluated as per Schedule 4 ( Part 2 and Part 5) of FSS regulations,2011 under Food Safety and Standard Act 2006 .A total of 24 catering establishments were included in the study. 
The Background Information of the Selected Catering Establishments

Out of 24 catering establishments 92\%(22) were running two shifts and only $8 \%(2)$ were having single shift. All the selected catering establishments were operational on all the seven days a week from 8:00am to $11: 00 \mathrm{pm}$.The total employees working in the catering establishments ranged between 40-80. The number of managers/supervisors working in the selected catering establishments were between 2 to 7.The other findings like seating capacity, number of customers visited them in a day, and number of coupons collected per day, types of cuisines served were gathered and the mean and percentages values were tabulated as shown in table 2 .

Table 2 : Background Information of the Catering Establishments

\begin{tabular}{|c|c|c|c|}
\hline $\begin{array}{l}\text { S } \\
\text { No }\end{array}$ & Variable & $\begin{array}{l}\text { Freque } \\
\text { ncy }\end{array}$ & Percentage \\
\hline \multirow[t]{5}{*}{1} & $\begin{array}{l}\text { Total Number } \\
\text { of Employees } \\
\text { Working }\end{array}$ & & \\
\hline & 40 & 2 & $8.40 \%$ \\
\hline & $41-60$ & 8 & $33.30 \%$ \\
\hline & $61-80$ & 6 & $25.00 \%$ \\
\hline & $80-100$ & 8 & $33.30 \%$ \\
\hline \multirow[t]{5}{*}{2} & $\begin{array}{l}\text { Number of } \\
\text { Shifts }\end{array}$ & & \\
\hline & One & 2 & $8.00 \%$ \\
\hline & Two & 22 & $92.00 \%$ \\
\hline & Three & 0 & $0.00 \%$ \\
\hline & Others & 0 & $0.00 \%$ \\
\hline \multirow[t]{4}{*}{3} & $\begin{array}{l}\text { Number of } \\
\text { Supervisors/ma } \\
\text { nagers }\end{array}$ & & \\
\hline & $<3$ & 6 & $25.00 \%$ \\
\hline & 4 to 6 & 9 & $37.50 \%$ \\
\hline & $>6$ & 9 & $37.50 \%$ \\
\hline
\end{tabular}

\begin{tabular}{|c|c|c|c|}
\hline & Others & 0 & $0.00 \%$ \\
\hline \multirow[t]{5}{*}{4} & $\begin{array}{l}\text { Number of } \\
\text { Customers visit } \\
\text { per day }\end{array}$ & & \\
\hline & $<200$ & 2 & $17.00 \%$ \\
\hline & $201-400$ & 4 & $8.00 \%$ \\
\hline & $401-600$ & 9 & $37.50 \%$ \\
\hline & $>600$ & 9 & $37.50 \%$ \\
\hline \multirow[t]{5}{*}{5} & $\begin{array}{l}\text { Seating } \\
\text { Capacity }\end{array}$ & & \\
\hline & 40 & 3 & $13.00 \%$ \\
\hline & $41-60$ & 2 & $8.00 \%$ \\
\hline & $61-80$ & 2 & $8.00 \%$ \\
\hline & $80-100$ & 17 & $71.00 \%$ \\
\hline \multirow[t]{5}{*}{6} & $\begin{array}{lr}\text { Number } & \text { of } \\
\text { Coupons } & \text { per } \\
\text { Day } & \end{array}$ & & \\
\hline & 200 & 3 & $12.50 \%$ \\
\hline & $201-400$ & 2 & $8.40 \%$ \\
\hline & $401-600$ & 6 & $25.00 \%$ \\
\hline & $>600$ & 13 & $54.10 \%$ \\
\hline \multirow[t]{6}{*}{7} & Cuisine Types & & \\
\hline & North Indian & 1 & $4.00 \%$ \\
\hline & Multi Cuisines & 23 & $96.00 \%$ \\
\hline & $\begin{array}{l}\text { Traditional } \\
\text { Cuisines }\end{array}$ & 0 & $0.00 \%$ \\
\hline & Any other & 0 & $0.00 \%$ \\
\hline & & $\mathrm{N}=24$ & \\
\hline
\end{tabular}

All the 24 catering establishments were holding FSSAI License at the time of study and thus complied the regulation 2.1 .2 of schedule 4 , FSSAI, 2011 which specifies that no person shall commence any food business unless they possesses a valid license. Conventional Service style was followed by $46 \%$ (11) and rest had Commissary Food Service 54\% (13) as shown in the table 3 below. 
Table 3 : Catering Establishments Service Style

\begin{tabular}{|l|l|l|l|}
\hline S & $\begin{array}{l}\text { Food Service } \\
\text { Operations } \\
\text { followed }\end{array}$ & $\begin{array}{l}\text { Frequenc } \\
\text { y }\end{array}$ & Percentage \\
\hline $\mathbf{1}$ & $\begin{array}{l}\text { Assembly Service } \\
\text { (Menu items } \\
\text { purchased,prepar } \\
\text { ed and minimal } \\
\text { cooking before } \\
\text { service) }\end{array}$ & 0 & $0.00 \%$ \\
\hline $\mathbf{2}$ & $\begin{array}{l}\text { Conventional } \\
\text { Service (Food } \\
\text { Items procured, } \\
\text { prepared,Served } \\
\text { in the premises) }\end{array}$ & 11 & $46.00 \%$ \\
\hline $\mathbf{3}$ & $\begin{array}{l}\text { Commissary Food } \\
\text { Service (Prepared } \\
\text { Food Distributed } \\
\text { from Central } \\
\text { Kitchen) }\end{array}$ & 13 & $54.00 \%$ \\
\hline $\mathbf{4}$ & Any Other & 0 & $0.00 \%$ \\
\hline & & $\mathrm{N}=24$ & \\
\hline
\end{tabular}

\section{Sanitation Survey of Selected Catering Establishments}

The sanitation survey was executed in all the 24 catering establishments using observation checklist which was developed using the pre-requisites of FSSAI system, Schedule 4 which need to be followed by Food Business Operators engaged in catering / food service establishments. The sanitation survey was having items like the location and surroundings, layout and designs, infrastructure facilities like wall, floors, air quality and ventilation, lighting, hand washing facilities and toilets, waste disposal, equipment and utensil washing facilities , procurement of raw materials and its storage, pest and rodent control, personal hygiene and health Status of food handlers, time and temperature control, food packaging and its distribution, food testing facilities, internal and external trainings and audit records, product information and consumer awareness .The mean sanitation survey score ,standard deviation, range, median and mode are shown in table 4 below for all the 24 catering establishments as a whole as well as separate for conventional and commissary food service providers.

Table 4 : The Sanitation Survey Scores : Mean, Standard Deviation, Range, Median and Mode of the selected catering establishment

\begin{tabular}{|l|l|l|l|l|l|}
\hline Catering Establishments & $\begin{array}{l}\text { Sanitation Survey } \\
\text { Mean Score }\end{array}$ & Std Dev & Range & Median & Mode \\
\hline $\begin{array}{l}\text { All selected catering } \\
\text { establishments (n=24) }\end{array}$ & 135.41 & 17.199 & $\begin{array}{l}101-177 \\
(76)\end{array}$ & 133 & $\begin{array}{l}127,132,149 \\
\text { (Each appeared } \\
\text { two times) }\end{array}$ \\
\hline $\begin{array}{l}\text { Commissary Food Service } \\
\text { Providers } \\
\text { (n=13) }\end{array}$ & 140.31 & 19.529 & $\begin{array}{l}101-177 \\
(76)\end{array}$ & 136 & $\begin{array}{l}\text { All values } \\
\text { appeared just } \\
\text { once }\end{array}$ \\
\hline $\begin{array}{l}\text { Conventional Food Service } \\
\text { Provider ( n=11) }\end{array}$ & 129.64 & 12.444 & $\begin{array}{l}112-149 \\
(37)\end{array}$ & 129 & $\begin{array}{l}\text { All values } \\
\text { appeared just } \\
\text { once }\end{array}$ \\
\hline
\end{tabular}


The sanitation survey outcome is depicted in figure 2 below which clearly indicates that none of the selected catering establishment could score A+ grade. Only $8 \%(2)$ of the catering establishments got $\mathrm{A}$ grade which represent North East and South West Districts whereas 20.8\%(5) needed improvement and got $\mathrm{B}$ grade. These catering establishments were operating in North, North west and South District. The more alarming and compromising situation was that $70.8 \%(17)$ of the catering establishments could not confirm to food safety standards operating procedures guidelines and did't qualify for any grade. These establishments were from East, West, South, Central, South West, North West and New Delhi Districts (figure 3).It had been mentioned by the 95.8\% (23) of the catering establishments that no food safety official had visited their selected catering establishment for assessments during the period of study and the previous year which was the violation of the norm by the food safety officials as mentioned in section 2.1.2, Schedule 4 ( FSSAI,2011).

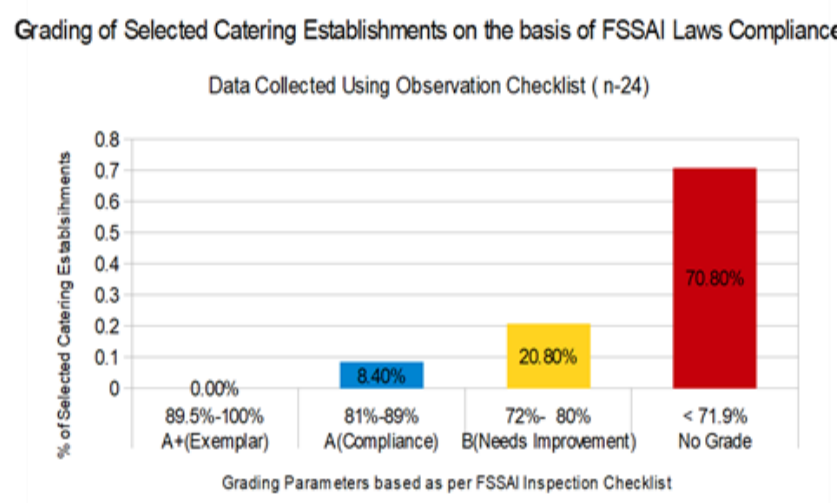

Figure 2 : Grading of Selected Catering Establishment

Catering establishments were expected to adhere to the set standards but the sanitation survey scores had surfaced their unsafe practices as shown in figure 2 .

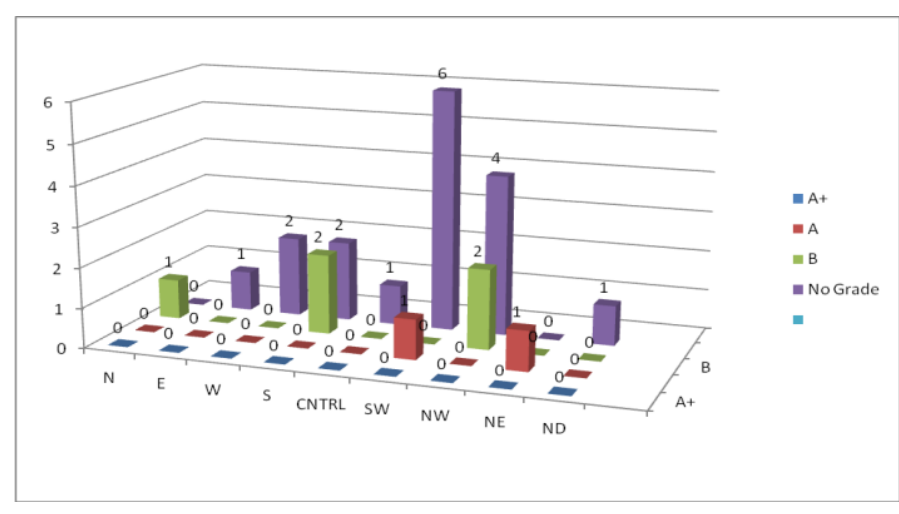

Figure 3 : District wise Grading of Catering Establishments $(\mathrm{n}=24)$

\section{Location and Infrastructure Facilities}

During the study it was found that only 50\% (12) of the catering establishments were not operating in industrial and residential areas but were operating in malls and the rest $50 \%$ (12) were operating in industrial and residential areas. As shown in table 5 only $87.5 \%$ (21) of the catering establishments were adhering to floor standards but the smooth and painted walls were found only in $25 \%$ (6) of the catering establishments. Sufficient Lux levels ,LED and covered lights were not being maintained and used. Air quality was also not maintained by $92 \%$ (22) of the catering establishments and smoke nuisance was observed in the kitchen as well as in service area of the restaurant. Potable water was supplied by only $75 \%$ (18) .The potable water lab reports were shown by only $25 \%(6)$ catering establishments. Water leakage was also observed in 50\%(12) of the catering establishments.This shows that maintenance of the facility was neglected.

Table 5 : Layout, Design and Infrastructure Facilities of Catering Establishments ( $\mathrm{n}=24$ )

\begin{tabular}{|l|l|l|}
\hline Layout and Design & Frequency & Percentage \\
\hline $\begin{array}{l}\text { Clean and well } \\
\text { maintained floors }\end{array}$ & $87.5 \%$ & 21 \\
\hline $\begin{array}{l}\text { Painted and Smooth } \\
\text { Walls }\end{array}$ & $25 \%$ & 6 \\
\hline Covered lights & $13 \%$ & 3 \\
\hline Sufficient Lux Levels & $46 \%$ & 11 \\
\hline
\end{tabular}




\begin{tabular}{|l|l|l|}
\hline Water leakage & $50 \%$ & 12 \\
\hline Self Closing Doors & $4.2 \%$ & 1 \\
\hline PVC Strips on doors & $16.6 \%$ & 4 \\
\hline Air Curtains working & $46 \%$ & 11 \\
\hline $\begin{array}{l}\text { Air Quality with } \\
\text { smoke }\end{array}$ & $8 \%$ & 2 \\
\hline $\begin{array}{l}\text { Supply of Potable } \\
\text { Water }\end{array}$ & $75 \%$ & 18 \\
\hline
\end{tabular}

\section{Personal Hygiene and Health Policy}

Uniform distribution was restricted to the food handlers working at food service counters as shown in table 6 . The food handlers were seen wearing street shoes and personal clothing inside the food preparation area . Restriction policy was also displayed in 54\% ( 13) of the catering establishment but it was not enforced on the shop floor. Similarly, behavioral and personal cleanliness Do and Don't boards were displayed and enforced in just 33.3\%(8) catering establishments. None of the catering establishment $100 \%$ (24) could produce food handlers medical fitness certificate as per the standard performa recommended by FSSAI . First aid boxes were not maintained and not being replenised on timely basis . Expired medicines were found in the first aid box and no certiifed first aid trainer was available in these catering establishments.

Table 6 : Personal Hygiene Policy Implementation Status of Catering Establishments $(\mathrm{n}=24)$

\begin{tabular}{|l|l|l|}
\hline $\begin{array}{l}\text { Personal Hygiene } \\
\text { Variables }\end{array}$ & Frequency & $\begin{array}{l}\text { Percenta } \\
\text { ge }\end{array}$ \\
\hline Uniform Distribution & & \\
\hline $\begin{array}{l}\text { Both Front and back end } \\
\text { employees }\end{array}$ & 0 & $0.00 \%$ \\
\hline $\begin{array}{l}\text { Only Front end employees } \\
\text { (Service Counters) }\end{array}$ & 22 & $91.6 \%$ \\
\hline No uniform provided & 2 & $8.4 \%$ \\
\hline $\begin{array}{l}\text { No provision of Lockers } \\
\text { and Change Rooms }\end{array}$ & 23 & $95.8 \%$ \\
\hline Enforcement and display & 13 & $54.20 \%$ \\
\hline
\end{tabular}

\begin{tabular}{|l|l|l|}
\hline $\begin{array}{l}\text { of Restriction Policy : } \\
\text { Jwellery Policy/Mobile } \\
\text { Policy/ }\end{array}$ & & \\
\hline $\begin{array}{l}\text { Do and Don't board } \\
\text { displayed and enforced }\end{array}$ & 8 & $33.3 \%$ \\
\hline $\begin{array}{l}\text { Availability of Medical } \\
\text { Fitness Certificate }\end{array}$ & 0 & $100 \%$ \\
\hline $\begin{array}{l}\text { First Aid Box available but } \\
\text { not maintained }\end{array}$ & 23 & $96 \%$ \\
\hline
\end{tabular}

\section{Hand washing Facilities : A legal Obligation}

During study visits, it was observed that $91.7 \%$ (22) of the catering establishments failed to provide hand washing facilities as shown in figure 4 . None of the catering establishment $100 \%$ ( 24) had the provision of supplying hot and cold water at hand washing stations with paddle operating taps. Also 70.8\%(17) had no regular supply of consumables like liquid soap and paper towels. In the absence of liquid cleansers or soap , the food handlers were washing hands with just plain water or with Nirma ( detergent used for washing clothes). Air dryer or one time use paper towel were not provided by $87.5 \%(21)$. catering establishments. Sanitizer dispensers were provided by $62.5 \%$ ( 15 ) of the catering establishments at the entry points of production and service counters but food handlers were sanitizing their hands as a replacement of hand washing process specially before netering in servie counters as there was no provision of hand washing.

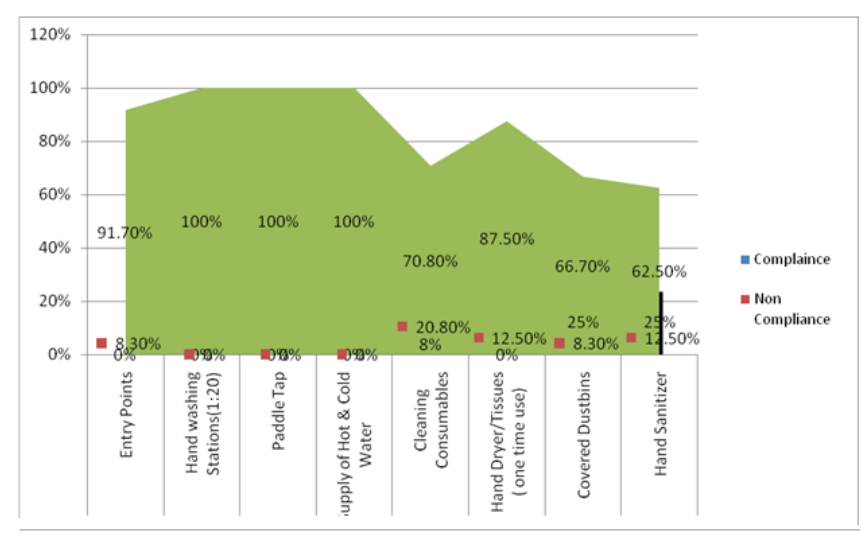

Figure 4 : Hand Washing Facilities Status in the selected Catering Establishments $(\mathrm{n}=24)$ 


\section{Material Handling}

As seen from table 7 , all the $100 \%(24)$ catering establishments were procuring food items from the FSSAI approved vendors. Only 37.5\%(9) catering establishments were checking the quality of received food items using product specification checklist but all 100\% (24) make sure to check the best before date on food items. Also none of the catering establishment were meeting the criteria of document specification from vendors like certificates of guarantee $(C O G)$ for raw materials and a certificate of analysis (COA) for ingredients, raw materials and packaging materials with each delivery. Infact, the employees including management and their vednors were not aware of these documents requirement. Before storing fruits and vegetables only $8.4 \%$ (2) catering establishments were sanitizing the fruits and vegetables and storing food items away from wall .Only 75\% (18) and 62.5\%(15) were following stock rotation using First In First Out (FIFO) and First Expired and First Out ( FEFO) respectively . It had also been observed that only $58.3 \%$ (14) of the catering establishmnets were using food grade containers and rest were substandards storage containers to store food items like polybags and one time used containers ( disposable containers).

Table 7 : Receiving and Storing of Raw Material at Catering Establishments ( $\mathrm{n}=24)$

\begin{tabular}{|l|l|l|}
\hline Material Handling & Frequency & Percentage \\
\hline $\begin{array}{l}\text { Receiving of Food } \\
\text { and Packaging } \\
\text { Material }\end{array}$ & & \\
\hline $\begin{array}{l}\text { Procuring Food } \\
\text { from FSSAI } \\
\text { approved Vendors }\end{array}$ & & $100 \%$ \\
\hline $\begin{array}{l}\text { Checking Quality } \\
\text { of received food } \\
\text { items using } \\
\text { Checklist }\end{array}$ & & \\
\hline
\end{tabular}

\begin{tabular}{|c|c|c|}
\hline $\begin{array}{lr}\text { Checking } & \text { Best } \\
\text { Before Date on } \\
\text { Food Packets }\end{array}$ & 24 & $100 \%$ \\
\hline $\begin{array}{lr}\text { Sanitation } & \text { of } \\
\text { Vegetables before } \\
\text { storing }\end{array}$ & 2 & $8.4 \%$ \\
\hline $\begin{array}{l}\text { Storing of Food } \\
\text { and Packaging } \\
\text { Material }\end{array}$ & & \\
\hline $\begin{array}{l}\text { Storing Food Items } \\
\text { away from wall }\end{array}$ & 2 & $8.4 \%$ \\
\hline $\begin{array}{l}\text { FIFO followed } \\
\text { while storing non } \\
\text { perishable food } \\
\text { Items }\end{array}$ & 18 & $75 \%$ \\
\hline $\begin{array}{l}\text { FEFO followed for } \\
\text { perishable food } \\
\text { items }\end{array}$ & 15 & $62.5 \%$ \\
\hline $\begin{array}{l}\text { Storage of food in } \\
\text { Food Grade } \\
\text { Containers }\end{array}$ & 14 & $58.3 \%$ \\
\hline $\begin{array}{l}\text { Using Non food } \\
\text { grade Polybags to } \\
\text { store food items }\end{array}$ & 22 & $91.7 \%$ \\
\hline $\begin{array}{l}\text { Using one time } \\
\text { Used Containers } \\
\text { for storing food } \\
\text { items }\end{array}$ & 22 & $91.7 \%$ \\
\hline
\end{tabular}

\section{Process Control}

It was evident from table 8 that $95.8 \%$ (23) of the catering establishments were using wooden chopping boards . Also, it was observed that only $25 \%$ (6) food establishments were using rational oven to thaw frozen foods and those who were not having the provision of rational ovens were thawing frozen foods at room temperature and none of them were using refrigerators and the methods recommended by FSSAI .Permitted and permissible color was used by $8.4 \%$ ( 2) catering establishments and for others no controls were observed. All 100\% (24) catering 
establishments were taking fresh oil once in the morning and during the day new oil was added in the used oil if , they require more oil for cooking food. The cooking of food was done at ideal temperature by $100 \%(24)$ of the catering establishments Time temperature abuse was observed in $95.8 \%$ (23) of the catering establishments while storing cooked food in refrigerators and cold rooms. Temperature of home delivered food was maintained by just $25 \%$ (6) of the catering establishments.

Table 8 : Process Control Procedures followed by Catering Establishments

\begin{tabular}{|l|l|l|}
\hline Process Control & Frequency & $\begin{array}{l}\text { Percentag } \\
\text { e }\end{array}$ \\
\hline $\begin{array}{l}\text { Using non wooden } \\
\text { chopping Boards }\end{array}$ & 1 & $4.20 \%$ \\
\hline $\begin{array}{l}\text { Using clean and } \\
\text { sanitized chopping } \\
\text { Boards }\end{array}$ & 2 & $8.40 \%$ \\
\hline $\begin{array}{l}\text { Thawing done in } \\
\text { Rational Oven }\end{array}$ & 6 & $25.0 \%$ \\
\hline $\begin{array}{l}\text { Thawing done in } \\
\text { refrigerator }\end{array}$ & 0 & $0.00 \%$ \\
\hline $\begin{array}{l}\text { Only required quantity } \\
\text { of food thawed at a time }\end{array}$ & 11 & $45.8 \%$ \\
\hline $\begin{array}{l}\text { Permitted and } \\
\text { permissible levels of } \\
\text { food additives were } \\
\text { used }\end{array}$ & 2 & $8.4 \%$ \\
\hline $\begin{array}{l}\text { New oil added in a day } \\
\text { in the used oil for deep } \\
\text { frying }\end{array}$ & 24 & $100 \%$ \\
\hline $\begin{array}{l}\text { Cooking of food at ideal } \\
\text { time and temperatures }\end{array}$ & 24 & $4.2 \%$ \\
\hline Food Storage in & 1 & $100 \%$ \\
\hline \hline
\end{tabular}

\begin{tabular}{|l|l|l|}
\hline $\begin{array}{l}\text { Refrigerator/Cold } \\
\text { room/DeepFreezer was } \\
\text { Covered ,Sorted } \\
\text { (Separate shelves for } \\
\text { Cooked and uncooked } \\
\text { foods ) and not } \\
\text { overfilled }\end{array}$ & & \\
\hline $\begin{array}{l}\text { Using insulated bags to } \\
\text { maintain temperature of } \\
\text { Home Delivery Food } \\
\text { items }\end{array}$ & 6 & $25.00 \%$ \\
\hline
\end{tabular}

\section{Waste Disposal Management}

As seen in table 9 that $100 \%$ ( 24) catering establishments had provided adequate numbers of waste bins at food service areas, production, storage areas and at both customers and employees toilet. Foot operated bins were provided by just $25 \%$ (6) of the catering establishments and other 75\% ( 18) were using bins with swing in pre-preparation and productions area. Outside dumpster lid was found closed in $70.8 \%$ (17) of the catering establishments and were lying away from production areas.

Table 9 : Waste Management Practices of Catering Establishments

\begin{tabular}{|l|l|l|}
\hline $\begin{array}{l}\text { Waste Management } \\
\text { Practices }\end{array}$ & Frequency & Percentage \\
\hline $\begin{array}{l}\text { Adequate number of } \\
\text { Dustbins in food service } \\
\text { area, production, storage } \\
\text { area, toilets ( employees } \\
\text { and customers) }\end{array}$ & 24 & $100 \%$ \\
\hline $\begin{array}{l}\text { Provision of foot } \\
\text { operated bins in } \\
\text { preparation and } \\
\text { production area }\end{array}$ & 6 & $25 \%$ \\
\hline \hline
\end{tabular}




\begin{tabular}{|l|l|l|}
\hline $\begin{array}{l}\text { Provision of Covered } \\
\text { waste bins in employees } \\
\text { toilet }\end{array}$ & 10 & $41.70 \%$ \\
\hline $\begin{array}{l}\text { Provision of Covered } \\
\text { waste bins in customer } \\
\text { toilet }\end{array}$ & 24 & $100.00 \%$ \\
\hline Liners in waste bins & 24 & $100.00 \%$ \\
\hline $\begin{array}{l}\text { Oustside Dumpster Lid } \\
\text { Closed }\end{array}$ & 17 & $70.80 \%$ \\
\hline
\end{tabular}

\section{Dish Washing Procedures}

Both machine and manual dish washing practices had been observed in the selected catering establishment as shown in table 10. Only $16.7 \%(4)$ were using three sink method for dishwashing and rest were using two sinks and plastic buckets. The washed utensils were also dried using dirty wipes by 91.7\% (22) of the catering establishments .These dirty wiping clothes provides a conducive environment for the growth of harmful bacteria that can have a very negative effect on health. Standard operating procedure for washing utensils was not found. The recommended steps to clean dishwashing are Pre scraping, washing, rinsing , sanitizing in $150 \mathrm{ppm}$ chlorine for two minutes and air drying was not being followed. This dishwashing job was considered to be menial job and not much attendtion was given by the owners, managers and food hanlders. Also it was observed that only $8.3 \%$ ( 2) of the catering establishments were storing utensils in upside down position (inverted) and rest others were not storing utensils correctly.

Table 10 : Dish washing practices of Catering Establishments

\begin{tabular}{|l|l|l|}
\hline Dish Washing Practices & Frequency & Percentage \\
\hline Machine dish washing & 3 & $12.50 \%$ \\
\hline
\end{tabular}

\begin{tabular}{|l|l|l|}
\hline $\begin{array}{l}\text { Manual dish washing in } \\
\text { three sink }\end{array}$ & 4 & $16.70 \%$ \\
\hline $\begin{array}{l}\text { Manual dish washing in } \\
\text { Plastic Buckets }\end{array}$ & 6 & $28.60 \%$ \\
\hline Air Drying Of utensils & 0 & $0.0 \%$ \\
\hline $\begin{array}{l}\text { Drying of utensils with } \\
\text { dirty wiping cloth }\end{array}$ & 22 & $91.70 \%$ \\
\hline $\begin{array}{l}\text { Storing washed and dry } \\
\text { utensils in upside down } \\
\text { position ( Inverted ) }\end{array}$ & 2 & $8.3 \%$ \\
\hline
\end{tabular}

\section{Pest Control}

Both chemical and non chemical methods to control pests in the premises had been adopted by the catering establishments as shown in table 11 . Denying entry of pest by covering and sealing all pest openings is a very good preventive approach but was implemented only in $12.5 \%(3)$ of the catering establishments but visible pests were not seen in 91.665\%(22) catering establishments.Glue pad Intra Elecrocuted Devices (IED) are recommended by FSSAI in processing area. But, $87.5 \%$ ( 21) of the catering establshments had violated theis norm.Chemical spraying of pesticides should not be done by inhouse team as per FSSAI rules and regulations. Pesticide treatment to be done through approved vendors and they would send their trained person for this procedure with approved chemicals. But , $12.5 \%$ ( 2) of the catering establishmnets had violated this norm.

Table 11 : Pest Management both chemical and non chemical methods at Catering Establishments

\begin{tabular}{|l|l|l|}
\hline Pest Control Methods & Frequency & Percentage \\
\hline $\begin{array}{l}\text { Chemical Method Contract } \\
\text { services }\end{array}$ & 21 & $87.50 \%$ \\
\hline Chemical Method by in & 3 & $12.50 \%$ \\
\hline
\end{tabular}




\begin{tabular}{|l|l|l|}
\hline house trained person & & \\
\hline $\begin{array}{l}\text { Using non permissible } \\
\text { chemicals }\end{array}$ & 2 & $8.30 \%$ \\
\hline $\begin{array}{l}\text { Non Chemical Method } \\
\text { Intra Elecrocuted } \\
\text { Devices(IED)\} : Glue Pad }\end{array}$ & 3 & $12.50 \%$ \\
\hline $\begin{array}{l}\text { Non Chemical Method } \\
\text { Intra Elecrocuted } \\
\text { Devices(IED)\}: Buster }\end{array}$ & 21 & $87.50 \%$ \\
\hline $\begin{array}{l}\text { Placement of Intra } \\
\text { Elecrocuted Devices(IED): } \\
\text { Wall mounted }\end{array}$ & 8 & $33.30 \%$ \\
\hline $\begin{array}{l}\text { Placement of Intra } \\
\text { Elecrocuted Devices (IED): } \\
\text { Hung on Ceiling }\end{array}$ & 2 & $8.40 \%$ \\
\hline $\begin{array}{l}\text { Placement of Intra } \\
\text { Elecrocuted Devices (IED): } \\
\text { Lying on floor }\end{array}$ & 14 & $58.30 \%$ \\
\hline $\begin{array}{l}\text { All pest entry points closed } \\
\text { premises }\end{array}$ & 3 & $12.50 \%$ \\
\hline $\begin{array}{l}\text { Exhaust Fans with Flaps } \\
\text { and lovers } \\
\text { clearance in rat traps }\end{array}$ & 2 & $8.40 \%$ \\
\hline Rats/Birds/Cats /Monkey & 22 & $5.80 \%$ \\
\hline
\end{tabular}

\section{Product Information and Consumer Awareness}

Food safety and hygienic practices followed by the catering establishments should be communicated to consumers so that they can make healthier and safer food choices while purchasing .Labeling standards on food packets as per FSSAI regulations,2011 was complied by all $100 \%$ (24) of the catering establishments . Whereas only $12.5 \%$ (3) of the catering establishments had displayed Food Safety Display Boards at a prominent location during the period of study and rest others $87.5 \%(21)$ were not aware of this FSSAI mandate as shown in table 12 .

Table 12 : Product Information and Consumer Awareness as per FSSAI Norms at Catering Establishments

\begin{tabular}{|l|l|l|}
\hline $\begin{array}{l}\text { Product information and } \\
\text { Consumer Awareness }\end{array}$ & Frequency & $\begin{array}{l}\text { Percenta } \\
\text { ge }\end{array}$ \\
\hline $\begin{array}{l}\text { Labeling on food Packets as } \\
\text { per FSSAI }\end{array}$ & 24 & $100.00 \%$ \\
\hline $\begin{array}{l}\text { Food Safety Display Board } \\
\text { Placed at Prominent } \\
\text { Locations }\end{array}$ & 3 & $12.50 \%$ \\
\hline $\begin{array}{l}\text { Regular Consumer Feedback } \\
\text { Procedures }\end{array}$ & 12 & $50.00 \%$ \\
\hline
\end{tabular}

\section{Monitoring and Testing}

As shown in table 13, regular internal audit been conducted in $54.2 \%$ ( 13 ) of the catering establishments and rest others were not complying this norm. Similarly only $25 \%$ (6) of the catering establishments were regularly getting their food and water samples tested from internal labs as well as from FSSAI accredited NABL labs .

Table 13 : Audit Control and Lab testing in Catering Establishments

\begin{tabular}{|l|l||l|}
\hline $\begin{array}{l}\text { Audit control and Lab } \\
\text { testing }\end{array}$ & Frequency & Percentage \\
\hline $\begin{array}{l}\text { Regular Internal Audit } \\
\text { Processes }\end{array}$ & 13 & $54.20 \%$ \\
\hline $\begin{array}{l}\text { Regular Lab Testing of } \\
\text { Samples }\end{array}$ & 6 & $25.00 \%$ \\
\hline
\end{tabular}




\section{Training Procedures}

As per Section 16(3)h of FSSA Act 2006, that all licensed food businesses must have at least one FoSTaC ( Food Safety Training and Certification) trained and certified Food Safety Supervisor for every 25 food handlers in each premise and all food handlers should be aware of their roles and responsibility in protecting food from contamination. It was found that catering establishments were not aware of this mandatory trainings and during study period only $20.8 \%(5)$ of the catering establishments were having FOSTAC certified Food Safety Supervisor and internal training program were also conducted by only $54.2 \%(13)$ of the catering establishments as shown in table 14.

Table 14 : Food Safety Training Control Procedures at Catering Establishments

\begin{tabular}{|l|l|l|}
\hline Food Safety Training & Frequency & Percentage \\
\hline $\begin{array}{l}\text { FOSTAC ( Food } \\
\text { Safety Training and } \\
\text { Certification) } \\
\text { Certified Training }\end{array}$ & 5 & $20.80 \%$ \\
\hline $\begin{array}{l}\text { Regular Internal } \\
\text { Training }\end{array}$ & 13 & $54.2 \%$ \\
\hline
\end{tabular}

Food Safety Plans, Food Allergen Policy and Important Record Maintenance by Catering Establishment

As per FSSAI regulation 2011, every catering establishment must have food safety plans, Allergen Plans and Standard Operating Procedures which ensures safe food production and hence prevents food borne outbreaks.It was observed that food allergen policy was not available in all the selected $100 \%(24)$ catering establishment whereas Food Safety plans were used by just $8 \%$ (2).It was also found that standard operating procedures guidelines were followed by only $54 \%$ ( 13) catering establishment as shown in figure 5.

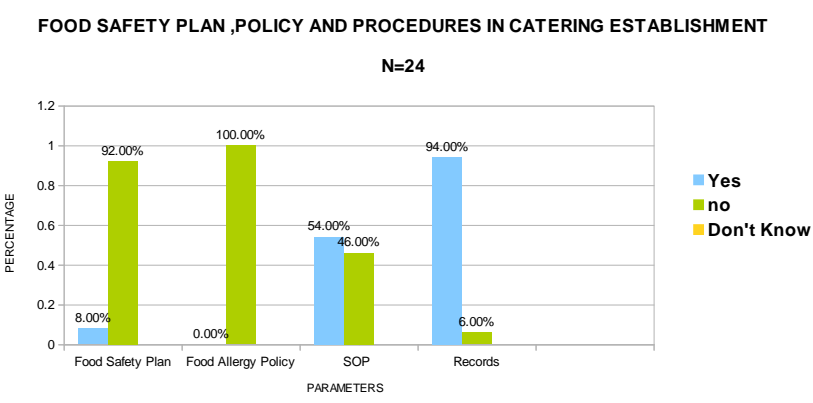

Figure 5 : Status of Food Safety Plan, Policy and Procedures

Proper Record maintenance related to hygiene, training and temperature is a pre requisite but on probing it was found that $29.2 \%$ (7) of the catering establishments were not maintaining any kind of hygiene, training and temperature records .Those who were maintaining temperature log books were not using calibrated thermometers as seen in figure 6 .

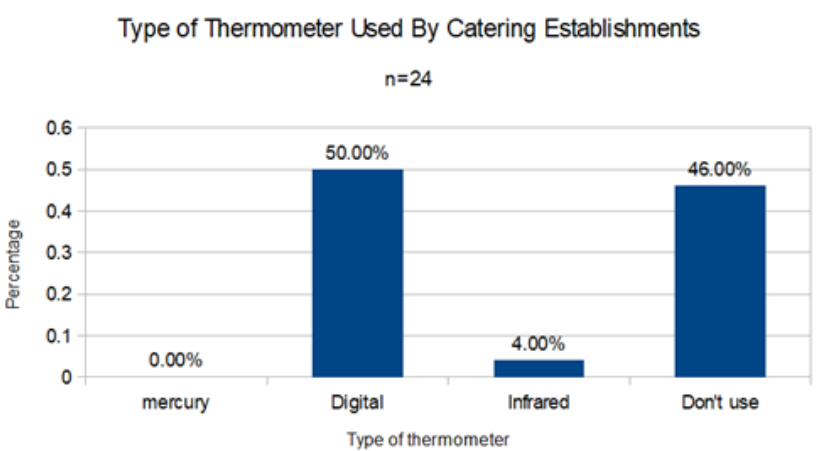

Figure 6 : Thermometer Usage Statistics by the Selected Catering Establishment

From figure 7 , it is clearly evident that the management had provided sub standard facilities to their employees. Six critical facilities (uniform, thawing procedure, records, hand washing facilities, potable ice and water) were compromised out of the seven highly critical norms, as per FSS regulations, 2011 , Part 5 , Scehdule 4 under FSS Act, 2006. The only norm fulfilled by all the actering establishment was cooking food at ideal temperatures. 


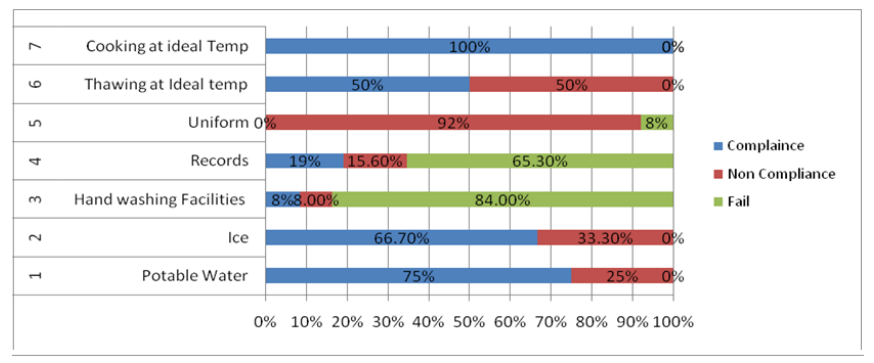

Figure 7 : Seven Priority Facilities as Per FSS

Regulations, 2011,Part 5, Schedule 4 Guidelines

\section{Discussion}

This study evaluated compliance to food safety and hygiene standards in the selected Delhi based catering establishments as per schedule 4 of Food Safety and standards Regulations 2011. . Upto 75\% (18) of the catering establishment were serving customers between 400 to 600 per day. This showed that the food preparations were liked by the consumers. As it is often said that product safety and quality is dependent on the prevailing sanitary conditions in the catering establishments and if poor sanitation level exists, then, it not only affects the shelf life of the product but there is also an increased risk of product contamination due to microbiological, chemical and physical hazards. The sanitation score was calculated using observational checklist which was based on schedule 4 of FSSAI regulation, 2011 under FSS Act 2006 with a focus on physical facilities like location , infrastructure facilities, purchasing, dish washing procedures, potable water source ,trainings, internal audits, consumer awareness, pest control, waste management, personal hygiene and hand washing facilities and maintenance of the premises. The mean sanitation survey score of all the 24 catering establishment was $135.41 \pm 17.19$ with a median and mode of 133 and 132 respectively. Poor sanitary condition is responsible for rapid growth and easy transmission of bacteria and other infectious agents (Fielding JE, Aguirre $A$ and Palaiologos E. 2001). Also the mean sanitation score of commissary and conventional food service providers was $140.31 \pm 19.529$ and $129.64 \pm 12.44$ respectively. To assess the significant relationship between the means of two different types of groups t- test was performed. It is one type of inferential statistics to test the claim.

\section{TESTING HYPOTHESIS}

(Null Hypothesis) Ho : There is no statistically significant difference between sanitation score of two groups.

Alternate Hypothesis ) Ha : There is a statistically significant difference between sanitation score of two groups.

T-Test was performed and the results are depicted in table 15. It is clearly evident from the table below that result is not statistically significant as the $p$ value is greater than 0.05 . Thus, the null hypothesis is accepted and there is no statistically significant difference between sanitation scores of two groups. Just higher sanitation score don't make commissary food service provider superior to conventional one. Mean scores of both groups 140 and 129 are not acceptable scores and both of them didn't qualify either for $A+$ or $A$ or $B$ grade. The scores are substandard which shows that both groups had not understood the compliances mentioned in schedule 4 of FSS act, 2006 or they were ignoring the set norms.

Table 15: $\mathrm{T}$ test calculation for two independent means for Commissary and conventional food provider at $\mathrm{p}<0.5$

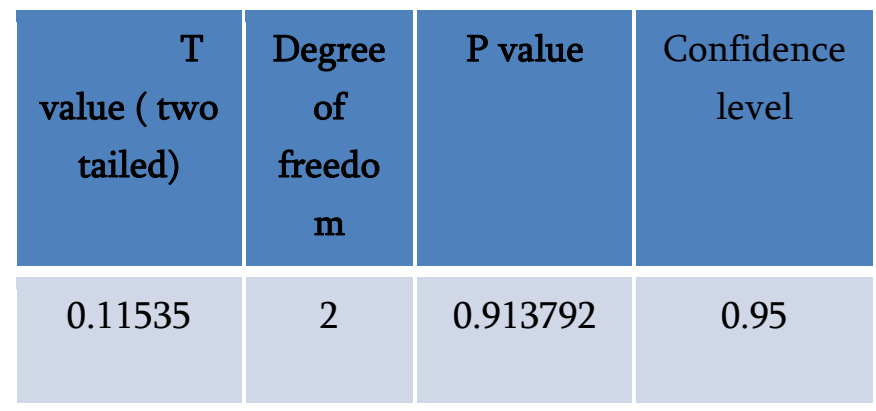


It is rightly said by Benjamin Franklin"It takes many good deeds to build a good reputation, and only one bad one to lose it". A food safety incident connected to the facility could cause significant costs through recalls, negative publicity, loss of customers, loss of credibility and lawsuits (Gardner S,1993).Broken floor, tiles and flaky paints were visible in catering establishments which could be due to poor implementation of preventive maintenance schedules. Similarly, poor implementation of cleaning and sanitation schedule was also observed . Dirty equipments, clogged ducts with oil and black soot on exhaust fans was visible. Air ventilation system was also not up to the mark. The smoke was seen in the dining area. All these conditions are favorable for the growth of various types of microbes and is also a good shelter for pests. According to FSSAI every catering establishment should implement an effective 4D ( Deny entry, Deny shelter, Deny food and destruction) approach for pest control program.

Many of the catering establishments had displayed grooming and hygiene posters to sensitize their employees but again the implementation on the shop floor was poor .The food service worker may contaminate food either in the preparation phase or the service phase. Therefore, the provision of adequate number of hand washing basins be provided and the same basins are not to be used for anything other than washing hands. But, it was found that there was no provision for separate washbasin in production area and the employees were forced to wash hands in vegetable and dish washing sinks.

Poor hand hygiene has been identified as a significant risk factor in spreading foodborne illnesses (Guzewich, 1995; Kilgore, Belay, Hamlin, Noel, Humphrey, Gary, Ando \&, Rosenthal 1996; Kassa, 2001). Further research in a laboratory setting (Daniels, Bergmire-Sweat, et al 2001), emphasizes that if food handlers become infected and/or equipment becomes contaminated with pathogens, poor hand hygiene could transmit the pathogens to customers. Lucey (2006) provides guidelines for proper handwashing procedures for food handlers. Employees should wash hands thoroughly with soap and hot water for at least 20 seconds. The handwashing facility should have liquid soap, hot water .Employees must wash and sanitize their hands thoroughly in a handwashing facility before starting work, especially if the employee has direct contact with food. The hands should also be washed after visiting the restrooms, after eating, drinking, smoking, chewing gum, chewing tobacco, coughing, using a handkerchief or tissue, and any other time when hands have become soiled or contaminated (FSSAI, 2011).

In order to avoid the potential hazards in food handling operations all the food establishments should systematically examine all of its processes from receiving to serving and relevant records to be maintained. Research conducted by Redmond, Griffith, Slader, and Humphrey (2004), further demonstrates that improper food handling practices can lead to dangerous contamination especially from raw foods. The World Health Organization (2013) with an intended mission to prevent the incidence of foodborne illness provides a simple guide to follow when preparing and serving food to others. The steps known as the "Five Keys to Safer Food" are: Keep clean; Separate raw and cooked; Cook thoroughly; Keep food at safe temperatures; Use safe water and raw materials.

As per the Centers for Disease Control and Prevention (CDC, 2013), poor personal hygiene of food handlers, along with improper temperature control are the two most significant factors leading to foodborne illness. It is always important to use calibrated thermometers as it ensures precise temperature everytime. Bacteria can easily grow with in $5-65$ degree $C$ which is known as is the 
danger-zone and if neglected can compromise food safety and lead to food borne outbreak or illnesses.

It was also observed that food safety plans, allergen plan and other records were not being maintained .These record are important which need to be maintained specially for high risk food items like milk, curd, cheese and cooked foods like rice, curries etc need to be stored and served at certain temperatures so that they remain fit for consumption. If these catering establishments were regularly monitored by the Food Safety Officer, their cleanliness scores would be more than the present one. Research has also proved that the catering establishments should be frequently inspected by external food safety officials and internal higher authorities as facilities that are regularly inspected had better sanitary and well maintained standards and conditions in comparison to uninspected ones.

Foodborne illness is a critical health concern that can impose substantial consequences. Training plays an important role in the prevention of food borne illness. The role of food workers in foodborne outbreaks has been clearly noted by several research studies (Todd, Greig, Bartleson, \& Michaels, 2009). According to the World Health Organization (WHO, 2013), 25 percent of foodborne outbreaks are closely associated with cross-contamination events involving poor hygiene practices, contaminated equipment, incorrect food processing, inadequate storage, and direct contamination by foodservice workers.Therefore, FSSAI recommends that all licensed food businesses must have at least one trained and certified Food Safety Supervisor under foSTaC for every 25 food handlers in each premise. It would promotes flawless execution and creates a better brand name for the organization.

\section{Product Information and Consumer Awareness}

A purple color Food Safety Display Boards which contains information like FSSAI registration/license number of the catering establishment and 12 golden rules of Food Safety and Hygiene shall be displayed at prominent locations which is easily visible to customers in the premises. This provides 360 degree assurance on food safety to customers. It also provides various options to consumers for sending feedback through WhatsApp, SMS or give feedback on FSSAI App. Also, all packaged food products should carry a label and requisite information as it serves as a primary link of communication between the producer and the buyer as per Food Safety Standards (Packaging \& Labelling) Regulations, 2011.

\section{CONCLUSION AND RECOMMENDATIONS}

Catering establishments were expected to adhere to the set standards but the sanitation survey scores had surfaced their substandard sanitary conditions which needs improvement as per FSS Act ,2006. FOSTAC training program is to be provided to the food handlers, managers and owners so that they can understand their legal responsibility and can adopt better control strategies to serve safe and wholesome food to consumers. Management commitment in providing sound infrastructure facilities would further motivate employees. The premises to be frequently inspected by external food safety officials and internal higher authorities as facilities that are regularly inspected had better sanitary and well maintained standards and conditions in comparison to uninspected ones.

\section{Abbreviations}

FSSAI:

Food Safety and Standard Authority of India FSS:

Food Safety Supervisor 
FOSTAC:

Food Safety Training and Certification

FSS Act ,2006 :

Food Safety and Standard Act, 2006

NABL

\author{
National accreditation of Board for Testing \\ and Calibration Laboratories
}

\section{REFERENCES}

[1]. Adams M, Motarjemi Y.1999.Basic Food Safety for Health Workers.WHO Geneva. Retrieved from

http://citeseerx.ist.psu.edu/viewdoc/download?do $\mathrm{i}=10.1 \cdot 1.385 .1166 \&$ rep=rep1\&type=pdf. $\quad$ Last reviewed on 25th Nov 2018.

[2]. Anon, 2011. Food hygiene regulations. Official Journal of the Republic of Turkey . Retrieved from

https://www.intechopen.com/books/significanceprevention-and-control-of-food-related-

diseases/food-safety-problems-and-solutions

Last reviewed on 25th Nov 2018 .

[3]. Center for Disease Control and Prevention. (2013). Retrieved from http://www.cdc.gov/ .Last reviewed on 4th Dec 2018.

[4]. CNN Wire, 2018.FoodBorne illness may be on the rise.Here's why. Retrieved from https://fox61.com/2018/07/23/foodborne-illnessmay-be-on-the-rise-heres-why/. Last reveiwed on 1st Dec, 2018.

[5]. Codex Alimentarius. 2009. Food Hygiene. Codex Alimentarius Commission, Joint FAO/WHO Food Standards Programme, Rome. Retrieved from https://www.intechopen.com/books/significanceprevention-and-control-of-food-relateddiseases/food-safety-problems-and-solutions Last reviewed on 25th Nov 2018

[6]. Cogan T. A., J. Slader, S.F. BloomWeld and T.J. Humphrey. 2002. Achieving hygiene in domestic kitchen: The effectiveness of commonly used cleaning procedures. Jour- nal of Applied Microbiology. 92: 885-892. Retrieved from https://www.intechopen.com/books/significanceprevention-and-control-of-food-related- diseases/food-safety-problems-and-solutions

Last reviewed on 25th Nov 2018

[7]. Choung. J, 2010. An Analysis of restaurant food safety violations: human factors, non-human factors, and food-borne illness" .UNLV Theses/Dissertations/Professional Papers/Capstones. Paper 458.

[8]. Collins, J. E. 2001. Impact of changing consumer lifestyles on the emergence/re-emer- gence of foodborne pathogens. Emerging Infectious Diseases. 3(4): 1-13. Retrieved from https://www.intechopen.com/books/significanceprevention-and-control-of-food-relateddiseases/food-safety-problems-and-solutions Last reviewed on 25th Nov 2018 .

[9]. Daniels, N.A., Bergmire-Sweat, D.A., Schwab, K.J., Hendriks, K.A., Reddy, S., Rowe, S.M., \& Atmar, R.L. (2000). A foodborne outbreak of gastroenteritis associated with Norwalk- like viruses: First molecular trace back to deli sandwiches contaminated during preparation. Journal of Infectious Disease, 181, 1467-1470. https://doi.org/10.1086/315365 . Last reviewed on 4rh Dec 2018.

[10]. Dudovskiy John.2018.Snowball Sampling. Retrieved from https://researchmethodology.net/sampling-in-primary-datacollection/snowball-sampling/. Last reviewed on 25th Nov 2018.

[11]. Fielding JE, Aguirre A and Palaiologos E, 2001. Electiveness of altered incentives in a food safety inspection program. Prev Med ; 32: 239-244.

[12]. Food Safety and standard Act 2006 , Rules 2011. International Law Book Company , 7th Edition . 2012

[13]. Food Safety Practices. 2018. Retrieved from https://assets.publishing.service.gov.uk/governme nt/uploads/system/uploads/attachment_data/file/7 57108/201810241-20_04_05_JSP_456_DCM_Pt_2_Vol_3__Ch_3_Food_Safety_Practices_Amnd_012.pdf. Last reviewed on 25th Nov 2018.

[14]. FSSAI, 2017. Guidance Document : Food Safety and Management System. Food Industry guide to Implement GMP/GHP Requirement. Catering Sector .Edition First. Online available at 
www.fssai.gov.in. Last reviewed on 25th Nov 2018.

[15]. FSMS,2017. Guidance Document: Food Safetya nd Management System.Food Industry guide to implement GMP/GHP requirement.Food Grain Warehouse.Edition First.Online available at www.fssai.gov.in. Last reviewed on 1st Dec,2018.

[16]. FSS Regulation 2011.Retrieved from https://www.fssai.gov.in/home/safe-foodpractices/FOOD-SAFETY-AND-HYGIENEREQUIREMENTS.html. Last reviewed on 25th Nov 2018.

[17]. Gardner, S. 1993 Consumers and food safety: A food industry perspective. Food and Agriculture Organization of the United Nations.

[18]. Gent RN, Telford DR and Syed Q.,1999 .An outbreak of Camphylobacter food poisoning at a university campus. Commun Dis Public Health ; 2:39-42.

[19]. Guzewich, J.J. (1995). The anatomy of a glove rule. Environmental Digest. Fall, 4-13.

[20]. Julie,Raj.2012.Food Culture of Delhi from https://dastaanjmc.wordpress.com/knowtheunkno wn/food-culture-of-delhi/).Last reviewed on 25th Nov 2018

[21]. Kibret $M$ and Abera B, 2012. The sanitary conditions of food service establishments and food safety knowledge and practices of food handlers in Bahir Dar Town. Ethiop J Health Sci ; 22(1):27_35.

[22]. Kassa, H. (2001). An outbreak of Norwalk-like viral gastroenteritis in a frequently penalized food service operation in Toledo, Ohio: A case for mandatory training of food handlers in food safety and hygiene. Journal of Environmental Health, 64(5), 9-33.

[23]. Kilgore, P.E., Belay, E.D., Hamlin, D.M., Noel, J.S., Humphrey, C.D., Gary, H.E., Ando, T., \& Rosenthal, D.S. (1996). University outbreak of gastroenteritis due to a small round- structured virus: Application of molecular diagnostics to identify the etiologic agent and patterns of transmission. Journal of Infectious Diseases, 173(4), 787-793.
[24]. Krueger RA \& Casey MA.2000 Focus Groups: A Practical Guide for Applied Research, 3rd ed. Thousand Oaks, CA: Sage Publications.

[25]. Lucey John , 2006. \{Personal Hygiene and food safety tips. Retrieved from https://www.foodqualityandsafety.com/article/per sonal-hygiene-and-food-safety/.Last reviewed on 26th Nov 2018.

[26]. Motarjemi, Y. et al. (1999) HACCP Principles and Practice - Teacher's Handbook. World Health Organization and Industry Council for Development.

[27]. Redmond, D.M., Griffith, C.J., Slader, J., \& Humphrey, T. (2004). Microbiological and observational analysis of cross-contamination risks during domestic food preparation. British Food Journal, 106(8), 581-597. https://doi.org/10.1108/00070700410553585 .

[28]. WHO FERG website: http://www.who.int/mediacentre/news/releases/2 015/food-safety/en/. Last reviewed on 1st Dec 2018.

[29]. World Health Organization (WHO). (2013). The five keys to safer food. Retrieved from http://www.who.int/foodsafety/consumer/5keys/e $\mathrm{n} /$. Last reviewed on 4th Dec 2018.

[30]. Temelli, S. and C.M.K. Şen. ve Anar, Ş. 2007. Determination of Hygiene Status of Meat Seperation and Cheese Production Workers' Hands (in Turkish). The Journal of the Faculty of Veterinary Medicine, Kafkas University.24 (1-23-4): $\quad$ 75-80. $\quad$ Retrieved from https://www.intechopen.com/books/significanceprevention-and-control-of-food-relateddiseases/food-safety-problems-and-solutions Last reviewed on 25th Nov 2018 